\title{
Front Matter: Volume 9762
}

, "Front Matter: Volume 9762," Proc. SPIE 9762, Advances in Photonics of Quantum Computing, Memory, and Communication IX, 976201 (16 August 2016); doi: $10.1117 / 12.2240466$

SPIE. Event: SPIE OPTO, 2016, San Francisco, California, United States 


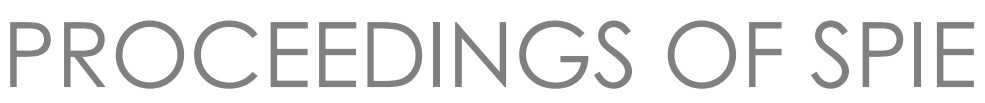

\section{Advances in Photonics of Quantum Computing, Memory, and Communication IX}

Zameer U. Hasan

Philip R. Hemmer

Hwang Lee

Alan L. Migdall

Editors

16-18 February 2016

San Francisco, California, United States

Sponsored and Published by

SPIE 
The papers in this volume were part of the technical conference cited on the cover and title page. Papers were selected and subject to review by the editors and conference program committee. Some conference presentations may not be available for publication. Additional papers and presentation recordings may be available online in the SPIE Digital Library at SPIEDigitallibrary.org.

The papers reflect the work and thoughts of the authors and are published herein as submitted. The publisher is not responsible for the validity of the information or for any outcomes resulting from reliance thereon.

Please use the following format to cite material from these proceedings:

Author(s), "Title of Paper," in Advances in Photonics of Quantum Computing, Memory, and Communication IX, edited by Zameer U. Hasan, Philip R. Hemmer, Hwang Lee, Alan L. Migdall, Proceedings of SPIE Vol. 9762 (SPIE, Bellingham, WA, 2016) Six-digit Article CID Number.

ISSN: 0277-786X

ISSN: 1996-756X (electronic)

ISBN: 9781628419979

Published by

SPIE

P.O. Box 10, Bellingham, Washington 98227-0010 USA

Telephone +1 3606763290 (Pacific Time) · Fax +1 3606471445

SPIE.org

Copyright (C) 2016, Society of Photo-Optical Instrumentation Engineers.

Copying of material in this book for internal or personal use, or for the internal or personal use of specific clients, beyond the fair use provisions granted by the U.S. Copyright Law is authorized by SPIE subject to payment of copying fees. The Transactional Reporting Service base fee for this volume is $\$ 18.00$ per article (or portion thereof), which should be paid directly to the Copyright Clearance Center (CCC), 222 Rosewood Drive, Danvers, MA 01923. Payment may also be made electronically through CCC Online at copyright.com. Other copying for republication, resale, advertising or promotion, or any form of systematic or multiple reproduction of any material in this book is prohibited except with permission in writing from the publisher. The CCC fee code is 0277-786X/16/\$18.00.

Printed in the United States of America.

Publication of record for individual papers is online in the SPIE Digital Library.

\section{SPIE. DIGITAL}

Paper Numbering: Proceedings of SPIE follow an e-First publication model. A unique citation identifier (CID) number is assigned to each article at the time of publication. Utilization of CIDs allows articles to be fully citable as soon as they are published online, and connects the same identifier to all online and print versions of the publication. SPIE uses a six-digit CID article numbering system structured as follows:

- The first four digits correspond to the SPIE volume number.

- The last two digits indicate publication order within the volume using a Base 36 numbering system employing both numerals and letters. These two-number sets start with 00, 01, 02, 03, 04, $05,06,07,08,09,0 A, 0 B \ldots$. OZ, followed by 10-1Z, 20-2Z, etc. The CID Number appears on each page of the manuscript. 


\title{
Contents
}

\author{
$\checkmark$ Authors \\ vii Conference Committee
}

NON-BLEACHING AND ULTRA-SMALL FLUORESCENT PROBES II: JOINT SESSION WITH CONFERENCES 9723 AND 9762

976205 Fluorescent nanodiamonds and their use in biomedical research (Invited Paper) [9762-4] QUANTUM OPTICAL ENTANGLEMENT FOR COMPUTATIONAL AND COMMUNICATION LINKS I

976209 The next iteration of the small photon entangling quantum system (SPEQS-2.0) [9762-8]

9762 OA Integrated quantum key distribution sender unit for daily-life implementations [9762-9]

\section{QUANTUM METROLOGY}

9762 OE Adaptive Gaussian quadrature detection for continuous-variable quantum key distribution [9762-13]

\section{HYBRID SYSTEMS AND QUANTUM TECHNOLOGIES}

9762 J Jn-chip quantum storage in a rare-earth-doped photonic nanocavity [9762-18]

PHOTONICS-BASED PHYSICS SIMULATIONS AND FEW PHOTON NONLINEARITIES I

9762 OP Quantum phenomena in ultra-high $Q$ whispering gallery mode resonators and applications to quantum information systems [9762-24]

PHOTONICS-BASED PHYSICS SIMULATIONS AND FEW PHOTON NONLINEARITIES II

9762 OR Few-photon control in nanometer-scale engineered fiber devices (Invited Paper) [9762-26]

PHOTONICS-BASED PHYSICS SIMULATIONS AND FEW PHOTON NONLINEARITIES III

9762 OV Towards four-dimensional photonics (Invited Paper) [9762-30] 
9762 OW Momentum-space Landau levels in arrays of coupled ring resonators (Invited Paper) [9762-31]

\section{POSTER SESSION}

$97620 \mathrm{X}$ Ultrathin fiber-taper coupling with nitrogen vacancy centers in nanodiamonds at cryogenic temperatures [9762-32]

$97620 Z$ Fabrication of high-quality nanobeam photonic crystal cavities in $\mathbf{4 H}$ silicon carbide with embedded color centers [9762-34]

976211 Characterization of type-Il spontaneous parametric down-conversion in domainengineered PPLN [9762-37] 


\title{
Authors
}

Numbers in the index correspond to the last two digits of the six-digit citation identifier (CID) article numbering system used in Proceedings of SPIE. The first four digits reflect the volume number. Base 36 numbering is employed for the last two digits and indicates the order of articles within the volume. Numbers start with $00,01,02,03,04,05,06,07,08,09,0 A, 0 B . .0 Z$, followed by 10-1Z, 20-2Z, etc.

\author{
Alghannam, Fahad S., 05 \\ Alkahtani, Masfer H., 05 \\ Bedington, Robert, 09 \\ Berceanu, Andrei C., OW \\ Bracher, David O., OZ \\ Campbell, Amanda R., 05 \\ Carson, William E., 05 \\ Carusotto, lacopo, ov, ow \\ Chandrasekara, Rakhitha, 09 \\ Chembo, Yanne K., OP \\ Corrielli, Giacomo, OA \\ Crespi, Andrea, $\mathrm{OA}$ \\ Durak, Kadir, 09 \\ Faraon, Andrei, 0J \\ Ferrier, Alban, OJ \\ Fujiwara, Masazumi, OX \\ Gerrits, Thomas, 11 \\ Goldman, Nathan, OV \\ Goldner, Philippe, 0J \\ Gyongyosi, L., OE \\ Hemmer, Phillip, 05 \\ Hu, Evelyn L., OZ \\ $\mathrm{Hu}$, Zhiwei, 05 \\ Ikeda, Kazuhiro, OX \\ Imre, S., OE \\ Kindem, Jonathan M., OJ \\ Kuo, Paulina S., 11 \\ Ling, Alexander, 09 \\ Ma, Lijun, 11 \\ Mélen, Gwenaelle, OA \\ Miyazono, Evan, 0J \\ Moritz, Charles E., 05 \\ Nam, Sae Woo, 11 \\ Noda, Tetsuya, ox \\ Osellame, Roberto, OA \\ Ozawa, Tomoki, OV, OW \\ Pejkic, Ana, OR \\ Price, Hannah M., OV, OW \\ Radic, Stojan, OR \\ Rampersaud, Arfaan A., 05 \\ Rampersaud, Isaac V., 05 \\ Rau, Markus, $\mathrm{OA}$ \\ Rochman, Jake, 0J \\ Septriani, Brigitta, 09 \\ Slattery, Oliver, 11 \\ Suarez-Kelly, Lorena P., 05 \\ Sumiya, Hitoshi, OX \\ Takeuchi, Shigeki, OX \\ Tang, Xiao, 11
}

Tang, Zhongkan, 09

Verma, Varun, 11

Villar, Aitor, 09

Vogl, Tobias, OA

Weinfurter, Harald, OA

Zhao, Hong-Quan, OX

Zhong, Tian, 0J 
Proc. of SPIE Vol. $9762976201-6$

Downloaded From: https://www.spiedigitallibrary.org/conference-proceedings-of-spie on 26 Apr 2023 Terms of Use: https://www.spiedigitallibrary.org/terms-of-use 


\section{Conference Committee}

Symposium Chairs

Jean-Emmanuel Broquin, IMEP-LAHC (France)

Shibin Jiang, AdValue Photonics, Inc. (United States)

Symposium Co-chairs

David L. Andrews, University of East Anglia (United Kingdom)

Alexei L. Glebov, OptiGrate Corporation (United States)

2016 Program Track Chair

Zameer U. Hasan, Temple University (United States)

Conference Chairs

Zameer U. Hasan, Temple University (United States)

Philip R. Hemmer, Texas A\&M University (United States)

Hwang Lee, Louisiana State University (United States)

Alan L. Migdall, National Institute of Standards and Technology

(United States)

Conference Program Committee

Dmitry Budker, University of California, Berkeley (United States)

Alan E. Craig, Montana State University (United States)

Jonathan P. Dowling, Lovisiana State University (United States)

Gurudev Dutt, University of Pittsburgh (United States)

Geoff J. Pryde, Griffith University (Australia)

David H. Hughes, Air Force Research Laboratory (United States)

Fedor Jelezko, Universität Stuttgart (Germany)

Marko Loncar, Harvard School of Engineering and Applied Sciences

(United States)

Aleksander K. Rebane, Montana State University (United States)

Matthew J. Sellars, The Australian National University (Australia)

Selim M. Shahriar, Northwestern University (United States)

Alan E. Willner, The University of Southern California (United States)

Jörg Wrachtrup, Universität Stuttgart (Germany)

Horace P. Yuen, Northwestern University (United States)

M. Suhail Zubairy, Texas A\&M University (United States) 
Session Chairs

1 Non-Bleaching and Ultra-Small Fluorescent Probes I: Joint Session with Conferences 9723 and 9762

Ramesh Raghavachari, U.S. Food and Drug Administration

(United States)

Philip R. Hemmer, Texas A\&M University (United States)

2 Non-Bleaching and Ultra-Small Fluorescent Probes II: Joint Session with Conferences 9723 and 9762

Ramesh Raghavachari, U.S. Food and Drug Administration (United States)

Philip R. Hemmer, Texas A\&M University (United States)

3 Quantum Optical Entanglement for Computational and Communication Links I

Hwang Lee, Lovisiana State University (United States)

4 Quantum Optical Entanglement for Computational and Communication Links II

Geoff J. Pryde, Griffith University (Australia)

5 Quantum Metrology

Olivier Pfister, University of Virginia (United States)

6 Hybrid Systems and Quantum Technologies

Sergey V. Polyakov, National Institute of Standards and Technology (United States)

7 Photonics-based Physics Simulations and Few Photon Nonlinearities I

Hannah M. Price, Università degli Studi di Trento (Italy)

8 Photonics-based Physics Simulations and Few Photon Nonlinearities II Alberto Amo, Laboratoire de Photonique et de Nanostructures (France)

9 Photonics-based Physics Simulations and Few Photon Nonlinearities III Andrey A. Sukhorukov, The Australian National University (Australia) 